\title{
Verbena 'Homestead Purple'
}

\section{Allan M. Armitage ${ }^{1}$,Jimmy S. Greer ${ }^{2}$, and James M. Garner ${ }^{3}$ Department of Horticulture, The University of Georgia, Athens, GA 30602-7273}

Verbena L. (Verbenaceae St.-Hil.) includes about 250 species of usually hairy, erect or decumbent to prostrate, annual or perennial herbs or subshrubs; most are native to tropical and subtropical North and South America (Griffiths, 1994). Six or seven species are in cultivation, of which $V$. $\times$ hybrida Voss is the most common (Armitage, 1997). Perennial species range in height from $\approx 1.3 \mathrm{~m}$ for $V$. bonariensis L. to $<10 \mathrm{~cm}$ for $V$. tenuisecta Briq. Verbena 'Homestead Purple', which may be a seedling of Verbena canadensis (L.) Britt., was selected for its early rose-colored flowers and coarse, lobed foliage (Armitage, 1995).

\section{Origin}

Verbena 'Homestead Purple' was discovered in a private garden near Athens, Ga., by A.M.M. and Michael A. Dirr in Mar. 1991. Seven cuttings were brought to The Univ. of Georgia horticulture greenhouses, where they were rooted. Plants from these cuttings were grown in 510-mL ( $10 \mathrm{~cm}$ diameter) containers and each stem produced rose-purple flowers in a terminal inflorescence $\approx 8$ weeks after planting.

\section{Description}

The plant produces rose-red flowers and opposite leaves (Fig. 1). Leaves are simple, deltoid to rhomboid, 3 to $5 \mathrm{~cm}$ long, and 2 to 3 $\mathrm{cm}$ wide, with an abruptly acute base and mucronate tip. The leaf base is narrowly tapering, with tissue continuing to the point of petiole insertion. On vigorous shoots the leaf margin is coarsely toothed, almost lobulate (Dirr, 1991). The leaves are green above (137C) and gray-green below (146-B) on the Royal Horticultural Society Colour Chart (Royal Horticultural Society, 1966). Both surfaces are prominently pubescent. The green stems are squarish and $<3 \mathrm{~mm}$ in diameter. The indeterminate inflorescence is a compacted spike containing 60 to 70 flowers from base to apex; 11 to 17 may be open at one time. The open flowers are positioned in such a manner that the inflorescence appears flat (Dirr, 1991). The flowers are five-petaled, salverform, 1.8 $\mathrm{cm}$ wide, with a corolla tube 1 to $2.5 \mathrm{~cm}$ long, narrow, pubescent, and whitish. The flowers are $<3 \mathrm{~mm}$ wide at the point where petals flare, with the corolla cut two-thirds of the way to

Received for publication 24 Aug. 2000. Accepted for publication 9 Dec. 2000. The cost of publishing this paper was defrayed in part by the payment of page charges. Under postal regulations, this paper therefore must be hereby marked advertisement solely to indicate this fact.

${ }^{1}$ Professor of Horticulture. E-mail: armitage@uga.edu ${ }^{2}$ Undergraduate Assistant.

${ }^{3}$ Graduate Research Assistant. center; each petal is slightly cleft and purple to violet on the outside (81-A), lighter underneath, and fragrant. Sepals are about one-third the length of the corolla tube, green and pubescent, with five acuminate, needle-like lobes. Stamens and pistil are inserted within the corolla tube. Sixty to 70 flowers make up the indeterminate inflorescence, which occurs in a spikose panicle that opens from base to apex. Eleven to 17 flowers in an inflorescence may be open at any one time.

\section{Performance}

Two plants, labeled as 'Homestead Purple', were placed in the trial gardens at The Univ. of Georgia in Spring 1991. Plants grown in USDA zone 7b (U.S. Dept. of Agriculture, 1990) begin to flower as the ground warms, and remain reproductive until frost. They form a clump 35 to $45 \mathrm{~cm}$ high and 1.0 to $1.3 \mathrm{~m}$ across. The habit is stoloniferous, and the shoots root readily in moist media. Full sun and welldrained soil are needed for optimal flower production. 'Homestead Purple' is probably cold hardy to about $-12^{\circ} \mathrm{C}$ (USDA Zone 6), as the temperature dropped to $-14^{\circ} \mathrm{C}$ during the winter before the plant was discovered.

In 1996, 36 different cultivars, including 'Homestead Purple', were evaluated at The Univ. of Georgia for floriferousness, vigor,

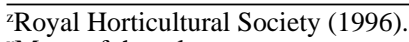

${ }^{y}$ Mean of three leaves. and overall health, and each plant was assigned an average performance rating from one to five, five being best. 'Homestead Purple' rated a 4 for the growing season and showed better performance in heat and humidity than all other cultivars evaluated (Armitage and Scoggins, 1996). The flower color of 'Homestead Purple' was considered to be unique among the cultivars we evaluated.

An additional study was conducted in July 2000 with 'Homestead Purple' and five similar cultivars to evaluate flower color, and shape and size of foliage (Table 1). 'Aztec Lavender Improved' resembled 'Homestead Purple' in flower color, but its laminae were more deeply lobed. 'Homestead Purple' seemed noticeably more fragrant than the other cultivars tested.

\section{Availability}

Plants are available through major plant brokers as well as from independent greenhouses throughout North America.

\section{Literature Cited}

Armitage, A.M. 1995. Verbena, what's going on out there? Greenhouse Grower 13(10):114-118.

Armitage, A.M. 1996. Verbena revisited. Greenhouse Grower 14(12):36-38

Armitage, A.M. 1997. Herbaceous perennial plants. 2nd ed. Stipes Publ., Champaign, Ill.

Dirr, M.A. 1991. Verbena. Nursery Manager 7(9):50.

Griffiths, M. 1994. Index of garden plants. Timber Press, Portland, Ore

Royal Horticultural Society. 1966. RHS colour chart. Royal Hort. Soc., London.

U.S. Department of Agriculture. 1990. USDA hardiness zone map. U.S. Dept. Agr. Misc. Pub. 1475

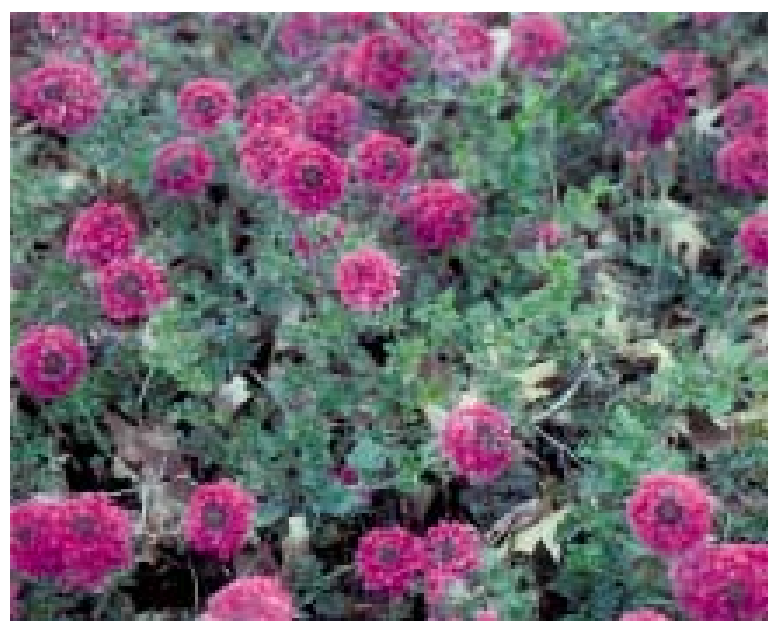

Fig. 1. Appearance of Verbena 'Homestead Purple'.

Table 1. Flower and leaf color, and leaf size for six Verbena cultivars.

\begin{tabular}{|c|c|c|c|c|c|}
\hline \multirow[b]{2}{*}{ Cultivar } & \multicolumn{3}{|c|}{ RHS color values $^{\mathrm{z}}$} & \multicolumn{2}{|c|}{ Leaf size $(\mathrm{cm})^{\mathrm{y}}$} \\
\hline & Flower & $\begin{array}{l}\text { Upper leaf } \\
\text { surface }\end{array}$ & $\begin{array}{c}\text { Lower leaf } \\
\text { surface }\end{array}$ & Length & Width \\
\hline Aztec Dark Purple Improved & $90-\mathrm{A}$ & 147-A & 135-D & 2.5 & 1.7 \\
\hline Aztec Lavender Improved & $81-\mathrm{A}$ & 147-A & $135-\mathrm{D}$ & 2.9 & 1.8 \\
\hline Aztec Pink Rose & $67-\mathrm{A}$ & $141-\mathrm{A}$ & 146-D & 3.3 & 2.2 \\
\hline Homestead Purple & $81-\mathrm{A}$ & $137-\mathrm{C}$ & $146-B$ & 4.8 & 3.0 \\
\hline Wildflower Rose & $66-\mathrm{A}$ & 139-A & $135-\mathrm{C}$ & 3.9 & 2.0 \\
\hline Radiance Blue & $93-\mathrm{A}$ & $137-\mathrm{A}$ & $139-\mathrm{C}$ & 4.9 & 2.2 \\
\hline
\end{tabular}

